\title{
Human Resource Management Between Economy and Ethics - Research of Serbia and Bosnia and Hercegovina
}

\author{
http://doi.org/10.21272/bel.4(3).127-136.2020
}

Azra Hanić, ORCID: https://orcid.org/0000-0001-6971-1706

Dr, Associate Professor, Faculty of Banking, Insurance and Finance, Belgrade Banking Academy, Belgrade, Serbia

Dragana Jevtić, ORCID: https://orcid.org/0000-0002-4431-9377

Master engineer of management, HR Manager, Vivex Company, Belgrade, Serbia

\begin{abstract}
This paper discusses economic and ethical issues that bring about certain limitations in human resource management as one of the basic organizational functions, through which the organization's relationship with employees is expressed. The aim of this paper is to point out the ethical dimension of human resource management as a key organizational function, which has economic, but at the same time ethical responsibilities. In elaborating this problem, we started from the basic assumption that human resource management as an organizational function and theoretical concept should balance between economic and ethical requirements, which depends on the attitudes of managers as decision makers. In addition to the analysis of the existing literature in this field, an empirical research was conducted to verify the stated assumptions on the basis of a survey questionnaire, which explored the attitudes of managers. The results were processed by statistical methods in the SPSS program. The significance of this paper derives from the importance of employees for the organization and the sensitivity of the human dimension of the organization in relation to the economic one. Bad condition in human resources management in $\mathrm{BiH}$ and Serbia, as the countries on which our research is focused, with unfavorable situation on the labor market, low level of perception of needs by managers and knowledge (professionalism) required for experts in this field to achieve necessary influence and affirm an effective concept and practice, opens opportunities for unethical actions of organizations. Unethical practices can be generated by ignorance, employers 'greed for quick profits, and weak institutional influence. High distance of power is an unfavorable cultural factor that encourages the arbitrariness of individuals and prevents social control of the behavior of organizations. In these wanderings and undefined directions of institutional development, in these countries there is room for corruption, poor law enforcement (incomplete reform of the judicial system), insufficiently defined protection of private property, strong influence of political parties in all spheres of life, political and economic connection, significant share of state property, etc. On the ground of egalitarian culture, high social inequality and impoverishment of the majority of the population is created, which negatively affects education, health and distracts attention from the civic control of the government. Therefore, in the research we started from the assumption that the primary evaluation of the human and social function of business and employees as a purpose, not a means, positively affects the ethical practice of human resource management, which we tested over the average response of respondents employed in different positions in the organization. The results obtained are presented in the paper.
\end{abstract}

Keywords: Business Ethics, Ethics, Employees, Economics, HRM, Organization.

JEL Classification: A12, O15.

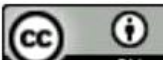

Cite as: Hanić, A., Jevtić, D. (2020). Human Resource Management Between Economy and Ethics - Research of Serbia and Bosnia and Hercegovina. Business Ethics and Leadership, 4(3), 127-136. http://doi.org/10.21272/bel.4(3).127-136.2020.

(C) The Authors, 2020. This article is published with open access at Sumy State University.

\section{Introduction}

The attitude towards employees is one of the most ethically sensitive issues in business. Managers have great potential to influence not only the performance of the organization, but also the lives of individuals, their families, and even various phenomena in society caused by deviant behavior. Regarding the issue of ethical 
responsibility of investors and managers and other actors in the organization, De George points out the contradiction of economic and ethical understanding. According to the economic understanding, shareholders' interests to return the invested amount are the highest and in the first place, "even if it can cause harm to the company in the long run" (De George, 2003: 203). However, countless situations in practice show that companies that are focused on profit in a short period to the detriment of other actors in business activities, usually do not survive in the market for a long time. The analysis of ethical theory shows that ethics, which has a normative and imperative character and deals with right and wrong (should - should not) behavior, seeks the supreme good as a universal value, according to which people can orient themselves in judgments about good or bad. It is also one of the key issues of ethics as a philosophical discipline. For business ethics, it is a man and his life. Business ethics starts from the assumption that in the economy we must not prioritize acting exclusively on the principle of economic rationality. Still, we should also consider the consequences of economic activities and business decisions for society, the environment and key actors. Compared to Kant's categorical imperative, the maxim of ethical affairs reads: Work in such a way that the effects of your work are acceptable for a quality human life on earth for a long time.

No matter how competitive a business is, it always exists based on common interests and mutually accepted conduct rules. These common interests represent a basic guideline in making ethical judgments about decisions and actions in business. Basically, it means that the purpose of the business is not a benefit (profit or earnings) only for one party, i.e. those who run the business, but a mutual interest for the beneficiaries of business activities. A business only makes sense if it is a socially useful activity and meets the needs of users of certain products and services. In defining the primary hypothesis for this research, a theoretical basis was found in the multidimensional framework of ethics in human resource management, highlighted by Kevin Wooten (Wooten, 2001: 164) in his work on ethical dilemmas in human resource management. Besides, a broader theoretical basis for the hypotheses in this study is found in the theoretical concept of human resource management in relation to ethics and professional codes of human resource management and theoretical approaches in business ethics that offer arguments for ethical analysis judgment of ethics (deontological approach in the part that refers to the relationship to a man as a purpose in itself, not a means, utilitarian approach that bases its argumentation on utility for most actors, stakeholder theory that refers to the interests of employees and Rows' theory of fairness, which offers criteria for determining fairness in proceedings against employees).

\section{Literature Review}

In the literature on business ethics, the issue of ethics in human resource management is not explicitly emphasized, but more in the context of employer-employee relations, managerial ethics (De George, 2003; Lenk, 1996; Berkel, Herzog, 1997; Lay, 1989; Krkač et al., 2007; DesJardins, 2006; Dramond, Bain, 2001) and decision making (Kraikebaum, 1996). These authors often focus on managerial ethics, corporate social responsibility, environmental ethics, marketing, and ethical challenges in international business. Although a relatively small number of authors have also addressed ethics problems in human resource management, very few have considered ethical issues through human resource management processes (Elisabeth Scott, 2005; Leopold, Harris, Watson, 2005). To a large extent, most authors' efforts are related to issues of employee rights, then to equality in terms of racial, national and gender diversity of the workforce in the global environment, as well as to corporate social responsibility, privacy, and data protection, etc. Thus Schuler and Huber (1993) focus their attention on HR information systems and privacy. Dessler (2005) points to potential ethical problems in the use of selection tests. Sherman et al. (1996) focus their ethical thinking on professional issues that arise in practice. Fisher, Schoenfeldt, \& Shaw (1999); Ivancevich (1998) Milkovich \& Boudreau (1998); Noe, Hollenbeck, Gerhardt \& Wright (1997); Schuler (1995) observed these is sues too. Cascio (1998) also devoted an entire chapter to ethics in the context of strategic decisions in HRM. However, it can be noted that a small number of authors explicitly analyze human resource management processes from an ethical point of view.

Within the literature review on this topic, it is especially important to point out the papers published in a special issue of the journal Personnel Review no. 5 of 1996 and topics raised at three conferences on ethical issues in contemporary human resource management held in 1996, 1998 and 2000. Among the authors of the titles that treated explicitly the ethics in human resource management there are Pinnington A., Macklin R., Campbel T. (2007). They deal with a set of issues in the context of the relationship between ethics and human resource management, then a group of authors published by Deckop J.R. (2006) with equally diverse matters in this field, while Kelechi J.E., Ekuma K.J., and Smith, J. (2012) point to the ethical dilemmas faced by HR professionals and managers in organizational practice. Scoville and Budd (2005) focus on ethics in human resource management from the 
perspective of industrial relations, and Harris H., Wijesinghe G., and McKenzie S. (2013) from the aspect of responsible management and managerial values. Jackson S., Ones D. and Dilchert S. (2012) go further and focus their attention on human resource management and protecting the living environment. As it can be seen from the literature review, theoretical sources mainly refer to American, British and, to some extent, German authors. The reason for this can be found primarily in the fact that both human resource management and business ethics, as theoretical frameworks of this issue, arose from American management concepts and schools. Although social, political, cultural and economic conditions are specific and differ in each country and geographical area, many management concepts that have proven effective in a market economy with a long tradition have been accepted and possibly modified and applied in other countries' practice.

Ethics and Human Resource Management. The links between ethics and human resource management derive primarily from the human and social character of this theoretical concept. By proclaiming the duality of human resource management goals (organizational goals and employee goals), i.e. creating management processes so as to enable the satisfaction of human needs through work to be at the same time an instrument for achieving organizational goals, it can be stated that the modern concept of human resource management denies that a man is a means to an end regarding organizational goals. The Harvard Analytical Framework for Human Resource Management (Beer et al., 1984: 16) was one of the first models to suggest that human resource management should ensure individual and social well-being and the achievement of organizational goals. It essentially assumes that organizations through human resource management policies, processes, and practices should not treat employees as a means, but as an end in themselves, which is one of Kant's categorical imperative principles.

Ethical responsibility towards employees includes, above all, respect for personality and dignity in relations at work, equality and non-discrimination, ensuring equal conditions for training and development, fair evaluation, promotion, remuneration and safe working conditions. They have moral obligations towards employees, which should be more than the agreed obligations and conditions. Compliance with contractual obligations and conditions falls within the legal responsibility level, and employers may not impose more requirements in these contracts than legal ones (e.g., renouncing pregnancy or marriage). Although academic and professional discussions on this theoretical concept are more focused on business effects and strategic importance, ethical issues in this area are also the subject of analysis in scientific and professional discussions. It is based on the necessity of harmonizing the economic and human dimensions of human labor. The interdependence between them has been proved in research since the beginning of the last century.

Even though this concept focuses on the cost and benefit (cost-benefit analysis) of the processes themselves, this direction results from the requirements for efficiency and lower prices that are a condition for the survival of modern organizations in a globally competitive environment. Human resource management activities are justified if they bring benefits to the organization. It causes the danger of ignoring the goals and needs of employees. The man in the organization is perceived as a mere means to achieve organizational goals. The focus on lower-cost efficiency in human resource management functions is not inherently unethical unless it is detrimental to employee interests. Human resource management abounds with ethical issues and challenges arising from the very nature of this professional and managerial activity. Every day, during decision-making, execution, and communication, managers can change, shape, redirect, and fundamentally change the course of other people's lives (Pinnington, Macklin \& Campbell, 2007). The decisions and judgments made by them relate to people and profoundly impact their lives, relationships and destinies, and the business and survival of organizations and their impact on the community's development, prosperity, mental and physical health. Nevertheless, it can be observed that issues of ethics in human resource management have been of marginal importance in academic discussions (Winstanley \& Woodall, 2000) and have received much less attention than issues of high performance, management of change and strategic role.

The question of whether a person is a means to achieve organizational goals or the purpose of entrepreneurial activities is often implicitly contained in certain understandings and theoretical approaches. If we look at the course of development of organizational theory and human resource management, we can see that the periods of focus on humanism and economism have changed. According to Winstanley and Woodall (2000), the peak of humanism was reached in the late 1960s and early 1970s, while the 1980s and 1990s brought demands to reduce costs and increase efficiency. A new series of demands to increase competitiveness on the global scene in recent decades has led to greater psychological pressures due to reduced staffing and relocation of production to areas with lower labor costs, then deteriorating health due to more stress, anxiety, insecurity and exhaustion from long hours. They believe that humanism is not in vogue in human resource management academic circles and is often considered an "ideological fallacy" (Winstanley and Woodall, 2000), especially 
by labor economics theorists. Attempts to strike a balance between economism and humanism are further jeopardized in everyday entrepreneurial practice, with the pendulum usually shifting in favor of employers and their often expressed aspiration for greater profits, sometimes bordering on greed. On the other hand, too much pendulum shifting to the side of employees can harm economic goals. In this sense, Woodall (1996) points out the danger of an overdose of paternalism and a narrowed perspective of employers, which could also jeopardize the values of diversity.

Key Ethical Issues in Human Resource Management. The key ethical question of human resource management arises from the relationship between the organization's goals and the goals of employees, i.e., whether the employees are a means to achieve organizational goals? The issue of conflict of interest between the organization and employees has been present since the beginning of industrial organizations' development when employees were treated to achieve organizational goals. Even then, one noticed the importance of meeting employees' goals through wages, after which a whole series of research was created within the school for interpersonal relations and the movement for the humanization of work, which focuses on the person (employees). Since then, periods of focus on economic (organizational) and employee goals have changed. Without disputing the importance of organizational goals, this issue can be viewed from another angle.

In achieving organizational goals, some alternative decisions and actions can harm individuals, society, and even the organization (Pinnington, Macklin \& Campbell, 2007). In this context, the question may be asked whether the goal justifies the means? Emphasizing the duality (harmony) and the equal importance of organizational goals and interests and goals of employees in the modern concept of human resource management seeks to avoid their opposition or conflict, contained primarily in economic theories in which social work is seen solely as a function of organizational goals or profits which serves to increase the value of invested capital. Neglecting the broader social interest of business organizations and work as human development needs leads to a narrowing of the ultimate purpose of business activities, and the impact on society and its development, and carries the danger of turning the race for profit into a short-term selfish action that can have unforeseeable consequences on a man and society in general. The duality of human resource management (organization and employees), emphasized in the modern concept, is transferred to the theoretical shaping of the process as a tool for best practices. Pinnington et al. (Pinnington et al., 2007: 238) call it an "ethical compass" that relies on procedural justice, extending it to a range of ethical challenges in performing these complex tasks. For them, the central premise of procedural justice is that people must be treated consistently and fairly. Perhaps most important in this way of looking at human resource management's ethical role is that the key challenges are not in the procedures themselves but in the necessity of different choices in making decisions that may harm some people, even if procedural justice is provided. Calling this a "necessary evil" that HR professionals cannot avoid in making decisions perceived as a greater good or purpose (for example, layoffs aimed at a greater well-being), special attention is paid to empowering HR professionals in addressing these ethically sensitive issues. It means raising awareness and "strengthening potential" in dealing with choosing between harmful consequences for one side for the good of the majority (Pininngton et al., 2007: 239). In doing so, typically, utilitarian argumentation "good for the majority" is accepted and used, and priority is given to organizational goals.

These authors believe that procedural justice, which should be provided by HR professionals, can help employees more easily accept decisions that are unfavorable to them. It does not raise the question of whether human resource management processes are set up to ensure fairness but assumes that only adherence to procedures can alleviate the perception of injustice. Pinnington et al. (Pinnington et al., 2007: 243) introduce procedural justice as a defense standard, designed to prevent violations of the rights and values of human beings with dignity as an affirmative standard, designed to promote respect for employees as human beings. Dignity is introduced here to "increase the lens of procedural justice." It focuses on preserving and enhancing the abilities and sense of people's identity, which is necessary to move on with life. Recognizing that the application of these standards does not guarantee the solution of HR professionals' ethical problem ("real possibility of distributive injustice"), the authors seek a solution in the third standard, which offers additional mechanisms as a basis for responding to this challenge. It refers to increasing the ability (capacity) of HR managers to resolve moral conflicts. The question is how to train managers to live with negative emotions, with nausea and multiple demands to meet organizational requirements and respect the dignity of victims simultaneously, how to be able to offer a job to one person and not to others, present a performance assessment or decide to transfer jobs from one location to another? Nevertheless, the authors believe that HR professionals' ethical problem is unsolvable since human resource management by its nature necessarily provides gains for some and losses for others. 
Ethics of human resource management implies more than the emotional treatment of people, fair treatment or prudence. As a solution to the ethical problem, Pinnington et al. (Pinnington et al., 2007: 249) see an increase in moral sensibility, rather than a retreat or a search for a solution to cognitive dissonance. The importance of the perception of someone who helps people is emphasized, and not someone who only carries out orders (courier). Although the modern concept of human resource management underscores the duality for goals that may seem to be the same as the goals of the organization and employees' goals, it is still about instrumentalizing employees' goals to achieve the organization's goals. In ethical analysis, there is a question whether in this way, the treatment of a man as a means is concealed and whether it endangers the dignity of a man as a purpose? In answering this question, it is necessary to consider the relationship between man and work. If work were exclusively a human necessity for survival, then employees' goals could be seen as an instrument for achieving organizational goals. It would then mean that a man is a means, which would conflict with Kant's essential ethical imperative. However, for a man, work is much more than a means of survival. A man develops and achieves his creative human being through work.

Work enables the realization of all human needs and especially the need for self-realization (self-actualization), which can be satisfied only through work. It means that an organization in which a person has the opportunity to work is a means to achieve a whole range of human needs. At the same time, it implies the possibility of achieving organizational goals and social needs through work. It places special ethical requirements on human resource management and HR professionals to ensure that human needs are met through policies, criteria and processes, which can be simultaneously in the function of achieving organizational (entrepreneurial) goals. It is a particular challenge that requires a high level of ethical awareness and management skills and the ability to carefully assess the situation while finding the best alternatives in the decision-making process. At the same time, it is necessary to apply the basic ethical principles: honesty, fairness and dignified treatment. Despite the critical comments regarding the position of a man in the gap between financial requirements for profit and ethical requirements for preserving human integrity in the process of achieving organizational goals, the theoretical concept of human resource management clearly emphasizes the balance of organizational (economic) and individual (social) goals. There is also an awareness that this balance is difficult to achieve in practice and depends on many factors, among which the attitude of key decision-makers is essential and their perception of the role and importance of employees to achieve organizational goals. The moral structure of their personalities is also essential. However, by applying the criteria for linking job requirements and personality potential, it is possible to achieve that balance significantly. At the same time, this principle hides the potential to meet employees' needs and interests, which allows respect for a man as a purpose, not a means. Thus, for example, applying job application criteria and its "matching" with appropriate candidates in the selection process makes it possible to meet the need for respect and self-actualization of individuals. Work is a human developmental need and doing work according to individuals' abilities creates a sense of selfsatisfaction and a sense of personal value and respect. People whose skills and potentials come to the fore at work and whose value system easily fits into the organization achieve identification with the job and the organization more quickly and easily, which is the basis of commitment.

The theoretical concept in this sense, contains both ethical and economic requirements through criteria and procedures that allow the application of these criteria. If the goal of the organization is to be efficient and competitive in the market, the criterion must be contained in the requirements of the job and the organization. Applying any other criterion leads to moral hazards. It should be noted that the application of this criterion is ensured by a procedure that should ensure fairness in the selection, promotion, evaluation and rewarding of those candidates or employees who, in relation to the requirements of the job and organization, have the best abilities and work results. Job and organization requirements as a criterion is the basis for making all decisions in human resource management. The second universal criterion is the work result. No matter how much work performance is valued in individual societies, it is not disputed that the global economy puts all organizations (and national economies) on the same start and sets efficiency-effectiveness as a key requirement. The concept of human resource management as a management function contains certain processes and clearly defined procedures, which have the capacity to ensure procedural justice and fairness in procedures and practices. Conceptually, these procedures and criteria should ensure objectivity and impartiality in decision-making.

Ethical problems Wooten (2001) views through the interchanging of internal (organizational, professional and personal ethics) and external ethical factors (economic and legislative climate, demographic and social trends) as a multidimensional framework of ethics in human resource management. It means that human resource management processes are finally ethically modified to interact with these internal and external factors. Even if operations are designed following ethical principles, in practice, there is always some room for actors themselves, or under the influence of professional or organizational requirements, to leave their ethical stamp 
in the procedural flow of activities and tasks. It is precisely the possibility of this balance that places exceptional professional and ethical demands on decision-makers. The practice of human resource management is continually taking place between the requirements of the organization and employees, which are often opposed, and the theoretical concept of human resource management is essentially based on the duality of their goals, which implies an appropriate balance. The connection between these goals is no less than their opposition, which is based on the basic fact that the achievement of organizational goals is directly dependent on employees, their loyalty, motivation and commitment.

\section{Research Results}

Within a broader research project (Hanić, 2017: 290), the attitudes related to the relationship between ethics and human resource management were also examined. A survey questionnaire was made, which consisted of several parts, as an integral part of broader research, only one segment of which is dealt with in this paper, to test our assumptions. The sample included 325 respondents, of whom 208 from Serbia and the remaining 117 from Bosnia and Herzegovina (BiH). In the group of respondents, $46 \%$ are female and $54 \%$ are male respondents. In this paper, the results of a part of the research are presented related to general understanding and attitudes of individuals towards business, its role in society, ethical boundaries of profit, the relationship between business and morality, law and business, and understanding business morality people. Attitudes express certain beliefs and form the basis for the formation of values, which guide individuals' behavior though, in certain situations, the behavior may differ from perspectives. Two groups of variables were used in the research, essential, studied or dependent variables, i.e., indicators that indirectly measure the phenomena, which were the subject of the research and explanatory variables that can explain the differences in the empirical manifestations of the studied phenomena. The answers are formulated via statements that express attitudes on a scale of $1-5$ which is transformed into a scale of -2 to +2 . The negative numbers $(-2$ and -1$)$ express negative attitudes, positive numbers (1 and 2) agree with the respondents with the stipulated statement, while 0 can be interpreted as a neutral or indeterminate respondent's attitude.

The following research methods and techniques were used to test research hypotheses: Descriptive analysis methods, which were primarily used for statistical evaluation of key parameters such as central tendency measures, measures defined in the form of proportions and dispersion measures, then correlation analysis methods, which were applied to examine the degree of quantitative agreement of the variability of the analyzed variables, various statistical parametric and nonparametric tests such as Z-test, t-test, F-test, Crombach-alpha test, variance analysis, multivariate analysis of variance, etc. The first attitude, which we checked, starts from the assumption that "business should bring as much money as possible in the short term". This attitude implies greed and short-term orientation, as opposed to ethically correct and proven in practice long-term approach to business as a socially useful and purposeful activity aimed at meeting human needs for products and services, rather than accumulating money for individuals. The ethical principle that business should serve society not the interests of individuals, is offered in the second section in this block "In business, only the interest of the owner should be taken into account". As our theoretical analysis shows, this selfish attitude is ethically unacceptable, as specifically pointed out by stakeholder theory, which extends responsibility for the impact of business on all stakeholders.

The third and fourth attitude which stipulate that "in the conditions of market orientation and competition, the unscrupulous win" refer to accepting the use of all means to gain profit as the main business goal. Acceptance of these attitudes presupposes the respondents' belief that the goal justifies the means, which is ethically unacceptable. In the first section, unscrupulousness in the circumstances of market pressure and competition was emphasized, and in the second, the justification of using all means to make a profit. The next section refers to the respondents' perception of the morality of businesspeople. Then three statements follow with which the respondents' understanding of the relationship between business and morality was tested and the possibility of a positive impact of morality on business results. The reason for testing these attitudes is the existence of opposed views of economists regarding the relationship between business and morality and the influence (negative or positive) of morality on business results. In the last section, the level of ethical understanding of business was tested, starting from the fact that the legal level of responsibility is the lowest level, which implies business agents' necessary behavior (under the threat of legal sanctions). In contrast, moral responsibility is choice and determination (virtue, character) and represents a higher level of liability than a legal responsibility. The offered set of attitudes towards employees aimed to determine the role of employees in entrepreneurial activities and attitudes and moral obligations of the organization towards employees. Many employers in a market economy, under pressure from competition and to make as much profit as possible, neglect employees as dignified human beings and treat them only as a means. 


\section{Discussion of Results}

Having in mind the level of significance of the attitude of respondents towards ethics in business and position in the organization, we started from the assumption that the primary evaluation of human and social function of business and employees as a purpose, not as a means positively affects the ethical practice of human resource management, based on differences in the mean values of the responses of respondents who are in different positions in the organization. After processing the data obtained from the survey, we presented the statistically processed results in the following table (Table 1).

Table 1. Attitudes of respondents with different job titles in the organization towards business

\begin{tabular}{|c|c|c|c|}
\hline $\begin{array}{l}\text { Your position in organization } \\
\end{array}$ & Mean & Std. Deviation & $\mathbf{N}$ \\
\hline \multicolumn{4}{|c|}{ The business should bring in as much money as possible in the short term } \\
\hline Top management & -.43 & 1.288 & 79 \\
\hline Middle management & -.34 & 1.308 & 94 \\
\hline Operating (executive) level & -.51 & 1.294 & 136 \\
\hline Human resources expert & -.75 & 1.238 & 16 \\
\hline Total & -.46 & 1.292 & 325 \\
\hline \multicolumn{4}{|c|}{ There is no room for the respect of needs and interests of others except for the owner's } \\
\hline Top management & -.97 & 1.320 & 79 \\
\hline Middle management & -1.12 & 1.144 & 94 \\
\hline Operating (executive) level & -1.04 & 1.270 & 136 \\
\hline Human resources expert & -1.31 & 1.014 & 16 \\
\hline Total & -1.06 & 1.233 & 325 \\
\hline \multicolumn{4}{|c|}{ In conditions of market competition, those who have the least scruples win } \\
\hline Top management & -.28 & 1.198 & 79 \\
\hline Middle management & -.13 & 1.330 & 94 \\
\hline Operating (executive) level & .35 & 1.297 & 136 \\
\hline Human resources expert & -.13 & 1.204 & 16 \\
\hline Total & .04 & 1.302 & 325 \\
\hline \multicolumn{4}{|l|}{ All means are justified in making profit } \\
\hline Top management & -1.05 & 1.208 & 79 \\
\hline Middle management & -1.06 & 1.216 & 94 \\
\hline Operating (executive) level & -.85 & 1.270 & 136 \\
\hline Human resources expert & -1.50 & .516 & 16 \\
\hline Total & -.99 & 1.218 & 325 \\
\hline \multicolumn{4}{|c|}{ Most business people do not stick to moral principles in business } \\
\hline Top management & .46 & 1.130 & 79 \\
\hline Middle management & .32 & 1.184 & 94 \\
\hline Operating (executive) level & .68 & 1.215 & 136 \\
\hline Human resources expert & .06 & 1.237 & 16 \\
\hline Total & .49 & 1.196 & 325 \\
\hline \multicolumn{4}{|l|}{ Business and morality cannot go together } \\
\hline Top management & -1.05 & 1.239 & 79 \\
\hline Middle management & -1.15 & 1.107 & 94 \\
\hline Operating (executive) lever & -.95 & 1.195 & 136 \\
\hline Human resource expert & -1.06 & 1.124 & 16 \\
\hline Total & -1.04 & 1.175 & 325 \\
\hline \multicolumn{4}{|c|}{ Morality in business does not affect business results in the long run } \\
\hline Top management & -1.04 & 1.192 & 79 \\
\hline Middle management & -1.02 & 1.235 & 94 \\
\hline Operating (executive) level & -.77 & 1.328 & 136 \\
\hline Human resources expert & -1.06 & 1.237 & 16 \\
\hline Total & -.92 & 1.266 & 325 \\
\hline \multicolumn{4}{|l|}{ Morality does not affect business success at all } \\
\hline Top management & -1.18 & 1.217 & 79 \\
\hline Middle management & -1.06 & 1.251 & 94 \\
\hline Operating (executive) level & -.98 & 1.302 & 136 \\
\hline Human resources expert & -1.56 & .629 & 16 \\
\hline Total & -1.08 & 1.245 & 325 \\
\hline \multicolumn{4}{|c|}{ Appart from the obligation to operate according to the law, organizations have no moral obligations } \\
\hline Top management & -.43 & 1.384 & 79 \\
\hline Middle management & -.60 & 1.339 & 94 \\
\hline Operating (executive) level & -.31 & 1.385 & 136 \\
\hline Human resources expert & -1.19 & .911 & 16 \\
\hline Total & -.46 & 1.362 & 325 \\
\hline
\end{tabular}

Source: Survey Data 
If we analyze the mean values of agreement with the attitudes of respondents in relation to business ethics according to the position in the organization, it can be concluded that the highest degree of disagreement with the statement that business should bring as much money as possible in the short term is found with human resources managers (mean -0.75), and the least expressed with middle management (-0.34), whose answers differ the most. This means that the middle management has the strongest belief that there is a need to gain money quickly in business. Such belief is somewhat less shared among the the top management (mean value -0.43). The answers are similarily arranged according to the claim that there is no room in business to respect the needs and interests of others other than the interests of the owners. The obtained results show that the degree of mutual consent of managers who are at different levels of management is different, with this degree of agreement being the highest among top managers (mean value -0.97 , with a high standard deviation of 1,320 ). The lowest degree of agreement with this statement exists among human resources experts (mean value -1.31 with a standard deviation of 1,014). With the statement that in conditions of market competition, those with the least scruples win, with the exception of those at the operational level, all respondents included in the sample generally disagree, and it can be noted that the degree of disagreement is highest in top management, although the mean $(-0.28)$ of the respondents' answers at these positions indicates a slight denial of this claim. This indicates a largely rooted belief about unscrupulousness in business.

Most of the respondents, regardless of their position in the organization, as a whole, do not agree with the statement that all means are justified in making profit. The highest degree of disagreement (mean value -1.50) and compactness of attitudes in this regard were expressed by human resources experts (deviation 0.516), while the lowest degree of disagreement with this attitude was expressed by respondents who are at the operational level. There are no significant differences between respondents in top management, middle management and human resources positions in terms of the disagreement degree with the view that business morality does not affect business results in the long run. It means that the sample includes respondents, regardless of their position in the organization, who believe that business morality has a long-term positive effect on business results. A somewhat lower level of disagreement with this statement can be observed among the respondents at the organization's operational level. On a centered scale from -2 (strongly disagree) to +2 (strongly agree), the overall mean is -1.04 because business and morality cannot go together, which shows that respondents generally disagree with this statement. However, while the mean value for respondents in managerial positions is approximate, for respondents at the operational level, it is the lowest (-0.95), while for top management, the response is the least homogeneous (standard deviation 1,239).

Generally speaking, all respondents, regardless of position, believe that most business people do not adhere to moral principles in business, with the average being in the middle of the segment from 0 to 1 of the used fivepoint scale (mean value 0.49). The respondents expressed the highest agreement with this statement at the operational level (mean value 0.68), and the lowest by human resource managers (mean value 0.06). Respondents mostly deny the view that morality does not affect the business success (the general average is -1.08), and in this case, the answers of human resources experts are the most pronounced (mean value -1.56) the most homogeneous. Respondents also disagree with the statement that organizations, apart from the obligation to do business according to the law, have no moral obligations. However, it is interesting that the lowest degree of disagreement is among the respondents at the operational level (mean value -0.31), and the highest among human resources experts (mean value -1.19). It can be noted that the degree of disagreement with this statement is significantly lower, with top managers (mean -0.43) and middle managers (mean -0.60).

Suppose we analyze results in general regarding attitudes related to business ethics among the respondents included in our sample. In that case, it can be seen that the attitudes of top management and middle management differ from the attitudes of human resources managers in terms of understanding the need for moral considerations in business, where the attitudes of the former (key decision-makers) can be understood as less ethical than the attitudes of human resources managers. Interestingly, respondents' attitudes in operational positions are significantly more harmful in terms of business ethics than other respondents' attitudes, which can be explained by the impact of their bad experiences and prejudices about capitalism and the market economy. Such attitudes of managers about business ethics represent a low basis for ethics in human resource management.

\section{Conclusions}

The theoretical analysis presented in this paper shows, above all, that human resource management, as a modern theoretical discipline and organizational practice in its very essence, implies ethical responsibility. It derives from the humanistic and social nature of human resource management. Since people are the basic initiators, executors and users of entrepreneurial activities, human resource management as a management 
activity has a special ethical role and responsibility. The professional public rarely raises ethics and ethical issues in human resource management. Issues of efficiency and impact on costs have been prevalent, which may obscure the human dimension of this organizational function. The fact that in practice, this function is under the pressure of achieving greater and greater economic results cannot justify neglecting the human dimension of work. Therefore, human resource management must reconcile ethical and economic requirements in practice. It originates from the very conflict of interests of employees and employers, reconciled through common goals. For this, however, human resource management professionals must respect some basic ethical postulates through policies, processes and procedures, such as fairness, fair dealing, dignity and equality. They will certainly sometimes be opposed to the demands for fast and increasing profits, which are placed before managers, but in the long run they can have a strong economic effect. Success in this depends equally on managers' attitudes towards employees and profit, as well as the ability of human resources professionals to influence them professionally. Our research has shown that the attitudes of managers and human resources experts differ in terms of the priorities of entrepreneurial activities, the importance and role of employees in these activities, and the ethical responsibility of employers. In this gap in their attitudes are the fields for ethical action and human resources professionals' influence. However, the more the pendulum of labor market shortages moves to one or the other extreme, the stronger or weaker the understanding of employees' ethical treatment will be.

Author Contribution. Conceptualization, Azra Sućeska; data curation, Azra Sućeska; formal analysis, Azra Sućeska and Dragana Jeftić; funding acquisition, Dragana Jeftic and Azra Sućeska; investigation, Azra Sućeska and Dragana Jeftić; methodology, Azra Sućeska; project administration, Azra Sućeska; resources, Azra Sućeska; software, Azra Sućeska; supervision, Azra Sućeska; validation, Azra Sućeska; visualization, Azra Sućeska; writing - original draft, Azra Sućeska; writing - review \& editing, Azra Sućeska.

Funding. There is no funding for this research.

\section{References}

1. Beer, M., Spector, B., Lawrence, P., Mills, Q., \& Walton, R. (1984). Managing Human Assets. New York, USA: Free Press. https://doi.org/10.1002/hrm.3930240310.

2. Berkel, K., \& Herzog, R. (1997). Corporate culture and ethics. Heidelberg, Germany: Sauer-Verlag. https://doi.org/10.1007/978-3-658-07820-1_25.

3. Budd J., \& Scoville J. (2005). The Ethics of Human Resources and Industrial Relations. Champaign, USA: Labor and Employment Relations Association. Available at: https://books.google.co.id/books?id=56dE7nLMNdoC\&printsec=frontcover\&hl=id\&source=gbs_ge_sum mary $\mathrm{r} \& \mathrm{cad}=0 \# \mathrm{v}=$ onepage $\& \mathrm{q} \& \mathrm{f}=$ false.

4. Cascio, W. (2003). Managing Human Resources. New York, USA: McGraw-Hill. Available at: https://pdfs.semanticscholar.org/05da/d8dc13d3b16932070ee01a6654f82540355d.pdf.

5. Deckop, J. R. (Edithor, 2006). Human Resource Management Ethics. Greenwich, UK: IAP. Available at: https://scholar.google.com/scholar?q=5.+Deckop,+J.+R.+(Editor,+2006).+Human+Resource+Manageme nt+Ethics.+Greenwich,+UK:+IAP.\&hl=sr\&as_sdt=0\&as_vis=1\&oi=scholart.

6. DesJardins, J. (2006). An Introduction to Business Ethics. New York, USA: McGraw Hill. Available at: https://pdfs.semanticscholar.org/0e84/1105cb5a2d650eb5aed1cf92b9031408a375.pdf.

7. Dessler, G. (2005). Human Resource Management. New Jersey, USA:Pearson-Prentice Hall. Available at: https://lib.ugent.be/en/catalog/rug01:002070662.

8. Di Džordž, R.T. (2003). Business Ethics. Beograd, Srbija: Filip Višnjić. Available at: https://www.knjizara.com/Poslovna-etika-Ricard-T-De-Dzordz-92924.

9. Dramond, Dž., \& Bein, B. (2001). Business Ethics. Beograd, Srbija: Klio. Available at: http://clio.rs/POSLOVNA-ETIKA Knjiga 162735.

10.Ekuma, K.J., \& Smith, J. (2011). Ethics in Human Resource Management. Saarbrücken, Germany: Lambert-Publishing. Available at: https://www.research.manchester.ac.uk/portal/en/publications/ethics-inhuman-resource-management(85429473-c73f-4ea1-a7c6-cca2b801134f).html.

11.Fisher, C. D., Schoenfeldt, L. F., \& Shaw, J. B. (1999). Human Resource Management (4th ed.). Boston, USA: Houghton-Mifflin. Available at: https://trove.nla.gov.au/work/3585931/version/261235479.

12.Hanić, A. (2017). Ethics in Human Resource Management. Beograd. 376 p. Available at: https://scholar.google.com/scholar?q=12.+Hani\%C4\%87,+A.+(2017).+Etika+menad\%C5\%BEmenta+lju $\underline{\text { dskih+resursa, }+ \text { Beograd. \&hl=sr\&as_sdt=0\&as_vis }=1 \& o i=\text { scholart. }}$ 
13.Harris, H., Wijesinghe, G., \& McKenzie, S. (2013). The Heart of the Good Institution:Virtue ethics as a framework for Responsible Management. Dordrecht, Netherlands: Springer. DOI:10.1007/978-94-0075473-7.

14.Jackson S., Ones D., \& Dilchert S. (2012). Managing Human Resources for Environmental Sustainability. San Francisco, USA: Jossey-Bass. Available at: https://www.amazon.com/Managing-Human-ResourcesEnvironmental-Sustainability/dp/0470887206.

15.Jose, A., \& Thibodeaux, M. S. (1999). Institutionalization of Ethics: The Perspective of Managers. Journal of Business Ethics, 22, 133-143.https://doi.org/10.1023/A:1006027423495.

16.Kreikebaum, H. (1996). Basics of business ethics. Stuttgart, Germany: Schäffer-Poeschel. Available at: https://www.amazon.de/Grundlagen-Unternehmensethik-Hartmut-Kreikebaum/dp/3825281116.

17.Krkač, K., et al. (2007). Introduction to Business Ethics and Corporate Social Responsibility. Zagreb, Hrvatska: Mate. Available at: https://www.mate.hr/product/4/k-krkac-uvod-u-poslovnu-etiku-ikorporacijsku-drustvenu-odgovornost.

18.Lay, R. (1989). Ethics for Manager. Düsseldorf, Germany: Econ Verlag. Available at: https://www.amazon.de/Ethik-f\%C3\%BCr-Manager-Rupert-Lay/dp/3430159164.

19.Leopold J., Harris L., \& Watson T. (2005). The Strategic Managing of Human Resources. Harlow, UK: Prentice Hall. Available at: http://resourcelists.ntu.ac.uk/items/7971CB37-FC26-09BA-CD508EF940BF7F4E.html.

20.Lepak, D. P., \& Snell, S. A. (2002). Examining the Human Resource Architecture: The Relationships Among Human Capital, Employment and Human Resource Configurations. Journal of Management, 28(4), 517-543. https://doi.org/10.1177/014920630202800403.

21.McLean, G. N. (2001). Ethical dilemmas and the many hats of HRD. Human Resource Management, 1(1), 13-32. https://doi.org/10.1002/hrdq.10.

22.Milkovich, G. T., \& Boudreau, J. W. (1998). Human resource management (6th ed.). New York, USA: McGraw-Hill. Available at: https://www.amazon.com/Human-Resource-Management-GeorgeMilkovich/dp/0256081530.

23.Noe, R. A., Hollenback, J., Gerhardt, B., \& Wright, P. (1997). Human resource management (2nded.). NewYork, USA: McGraw-Hill. Available at: https://www.mheducation.com/highered/product/humanresource-management-noe-hollenbeck/M9781260076844.html.

24.Winstanley, D., \& Woodall, J. (1996). Business ethics and human resource management. Personnel Review, 25(6), 5-12. https://doi.org/10.1108/00483489610148491.

25.Winstanley, D., \& Woodall, J. (2000). Ethical Issues in Contemporary Human Resource Management. Basingstoke, UK:Macmillan. Available at: https://www.macmillanihe.com/page/detail/ethical-issues-incontemporary-human-resource-management-diana-winstanley/?k=9780333739662.

26.Woodal, J. (1996). Managing culture change: can it ever be ethical? Personnel Review, 25(6), 26-40. http://dx.doi.org/10.1108/00483489610148518.

27.Wooten, K. (2001). Ethical dilemmas in human resource management. An application of a multidimensional framework, a unifying taxonomy, and applicable codes. Human Resources Management, 11, 159-175. DOI: $10.1016 / \mathrm{S} 1053-4822(00) 00045-0$. 